\title{
Obituary
}

\section{Dr. M. A. Ogryzlo}

Metro Ogryzlo of Toronto became suddenly and unexpectedly ill in Zurich at a meeting of the European League to celebrate its 50th Anniversary: he died soon after returning to Toronto on May 5, 1977. He is mourned not only by his immediate family, friends, and colleagues at the Wellesley Hospital and throughout Canada, but also by a much wider circle of rheumatologists in America and throughout the world. He was a particular friend of many people in this country: who, when visiting North America, had not visited with him and his group in Toronto and experienced their generous hospitality? It is the largest and one of the most productive rheumatology research units in Canada and this is due very largely to his organization and foresight, his choice of people, and his sheer pertinacity.

He had a most outstanding career. Graduating with a gold medal from the University of Manitoba in 1938, he enlisted in 1941 and served as consultant for 4 years in the Royal Canadian Air Force in the second world war. His 99 publications reflect the development of his interests from neuropathology in 1940 onwards to internal medicine, including spondylitis, in 1946, and thereafter to rheumatology, with research fellowships from a national research council and the Canadian Arthritis and Rheumatism Society. University appointments in 1952 led to assistant professorship in 1955, associate professorship in 1958, and to professorship in 1968. During this period he had pioneered modern rheumatology at Sunnybrooks Hospital from 1955 onwards as director of the clinical investigation unit. On moving to the Wellesley Hospital in 1966, he began an even more fruitful association which has led to an outstanding rheumatological department. This unit has trained young people from far and wide in rheumatology and sent its bright young fellows for postgraduate study abroad, including a large number to England, where we have known and appreciated them in our units as research fellows or residents, as visitors, or as associate members of the Heberden Society.

Met Ogryzlo took a very full share of responsibility on national and international committees as well as on more local commitments, including the review panel for the Gairdner awards, and was duly honoured by the American Rheumatism Association of which he was second vice-president 1975-1976 and by the Canadian Arthritis and Rheumatism Society which made him an honorary life member. One of his latest achievements was to start the Journal of Rheumatology (1974). This is now required reading on an international scale and is the only international medical scientific journal published in Canada. His was a life of great endeavour and great success both in the practice of medicine, in its science, and in its teaching. Dr. Hugh Smythe, his colleague for 27 years, epitomized him thus: ' $\mathrm{He}$ blended science and medical practice to the best benefit of the patient'. In all this he was greatly helped by his wife Gertrude, to whom with their three daughters we send our deepest sympathy.

E. G. L. BywATERS 